\title{
Lean Manufacturing Applications in the Manufacturing Industry
}

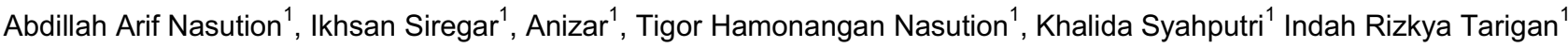 \\ ${ }^{1}$ Universitas Sumatera Utara, JI Almamater, Campus USU, Medan - Sumatera Utara, 20155
}

\begin{abstract}
This research was conducted in manufacturing industry, so this research is based on case study application. This research serves to reduce waste in the industry when making a product. This study categorizes value-added work and which work has no added value. And it is measurable and has value, so it can be evaluated in the future. Later this will be poured or depicted on a map called Value stream mapping. This is a tool from Lean Manufacturing. Lean manufacturing is useful for analysing and reducing non value-added activities, value stream mapping analysis tools, $5 \mathrm{~L} 1 \mathrm{H}$ process mapping activities, and 5 why tools. From the results of this study obtained the efficiency of the process cycle and total estimation of the improvement of the lead time. This calculation can be an evaluation material for the company.
\end{abstract}

\section{Introduction}

Competition nowadays is very rapid in the industrial sector, demanding every company engaged in manufacturing to improve business strategy. This research site is one of the manufacturing companies that produce electronic goods in North Sumatra. The production process that takes place in the company shows the existence of time that is not value added among others the inefficient material transfer in the raw material parts and molding the fan component still using manual way, the length of time waiting for the fan component after the next molding process on the raft at the assembly station. The length of production lead time in the fan production process in the company causes the company can not meet the needs of customers who have been ordered. These problems will adversely affect the company both financially and in partnership and show the lack of productivity of the company in increasing the production capacity of the fan product.

Lean Manufacturing is a set of techniques that when combined and run well will reduce and then eliminate waste [1]. Reducing waste is intended for all activities undertaken on the production floor is an activity that has value added activity, aims to improve competitiveness through the production process effectively and the use of resources efficiently. In this study, the effort made is to define the elements of the manufacturing cycle to reduce waste. The approach used is value stream mapping.

Value stream mapping is a process mapping tool that serves to identify the flow of material and information on the production process from raw material to finished product. Value stream mapping is represented by symbols which representing activity [2]. Activity is grouped into value added and non-value added, so it can be easily known which activity could give added value and those who do not give added value.

The successful application of lean manufacturing by using value stream mapping to reduce total lead time has been proven through scientific research [3]. In his journal that leads on current state maps of 29.43 days can be reduced to the inventory level of the process, which reduces inventory levels to 18.04 days to 15 days. This proves that the use of value stream mapping can reduce total lead time.

\section{Research method}

The research instrument used in this research is digital stopwatch used in data collection to measure the time of fan production process. Value stream mapping is used in data processing to visualize the real state of the production process and determine the classification of value added activity and non-value added activity. Observations made based on The Maytag Company that is with the provision of 10 times observations for activities that take place in the cycle of about 2 minutes or less while 5 times observation for activities that take place in the cycle time greater than 2 minutes.

\section{Result and discussions}

\subsection{Formation of current state map}

Current State Map is a description of the ongoing production process within the company covering material flow and information flow. The current state map consists 


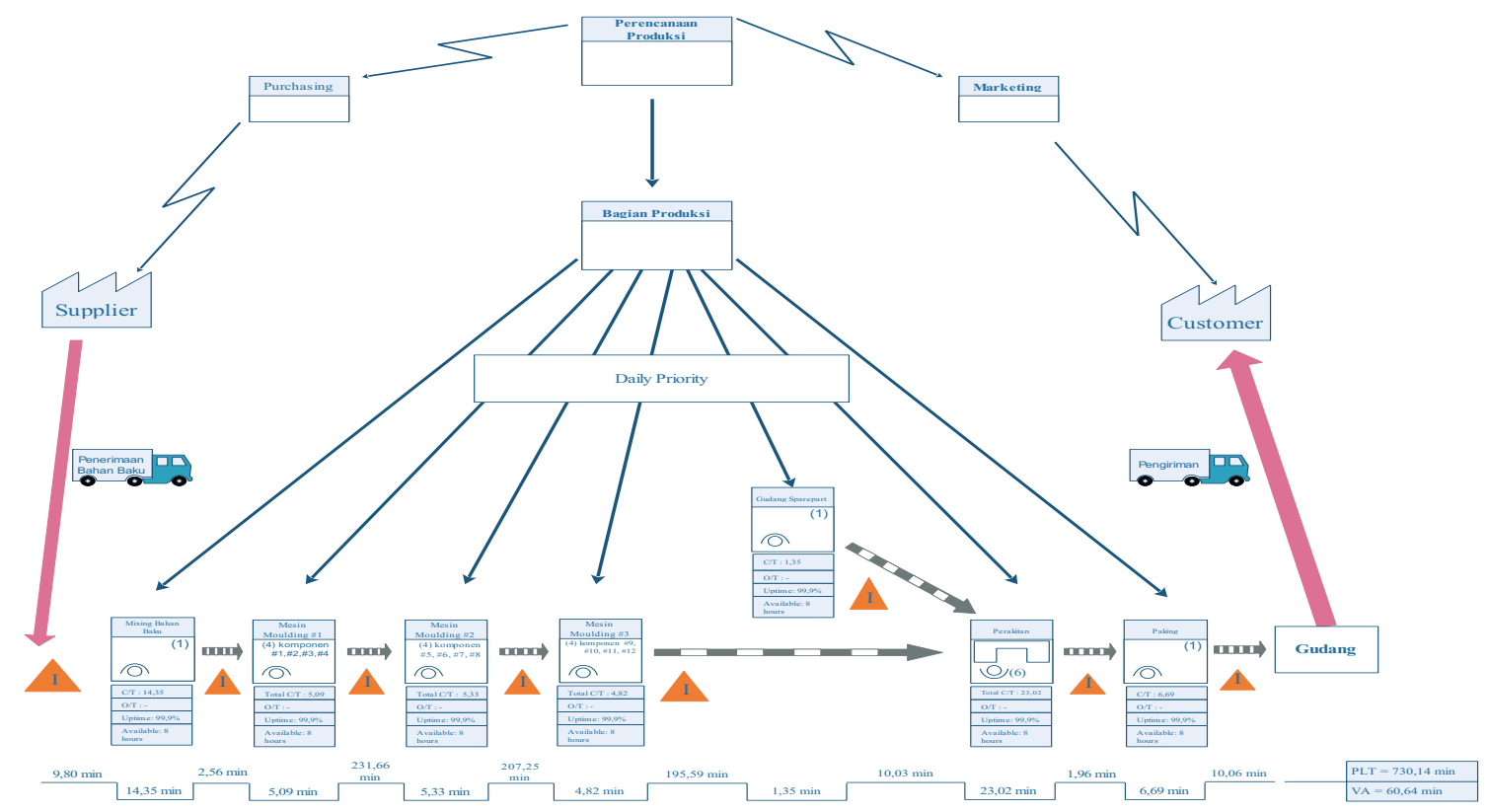

Figure 1. Current state map.

of several steps starting from determining the value stream manager to forming the entire plant flow map.

\subsubsection{Determination of value stream manager}

Value Stream Manager is someone who understands the whole production process that occurs in detail and has an important role in the production process so as to provide complete information and can assist in providing suggestions for improvement of production processes.

\subsubsection{Formation of SIPOC diagram}

SIPOC diagram used in this study to analyse and describe about how the process can provide services to customers. The formation of this diagram helps in explaining a complex project and its scope is unclear.

The elements used in the diagram are:

1. Supplier : Raw material storage warehouse and additional spare parts

2. Input : Plastic pellets, calcium carbo, colour flour, and additional spare parts

3. Process : Process stages that change from raw materials and spare parts into products.

4. Output

5. Customer : Consumer

\subsubsection{Overall map formation (current state map)}

At this stage each process along the value stream is combined with the flow of material and information into a single stream within the plant. Understanding of the two streams as follows:

\section{Material flow}

Material flow describes the movement of the main material in the process of production process along the value stream.

2. Information flow
The flow of information that companies use there are two types, namely:

a. Manual Information Flow

This information flow occurs between the production managers of each process that takes place on the production floor. The schedule given is the daily activity schedule after getting the adjustment of the amount of ingredients entered.

b. Electronic Information Flow

Information delivered using electronic devices. This information flow takes place between the production planning department and the marketing department, raw material suppliers, and between the marketing department and the customers.

Current state map that has been equipped with material flow and information flow and lead time bar can be seen in Figure 1. In making this current state map, the time is divided into two, ie production lead time indicating the existence of non-value added time and process time Cycle in the production process) which is value added time.

\subsubsection{Takt Time Calculation}

Takt time shows how often a product should be produced to meet consumer demand. Production time available with shift is 8 hours / day on Monday to Saturday. Rest period of 1 hour / day on Monday to Saturday. Within 1 month consists of 4 weeks and within 1 week there are 6 working days. [4]

$$
\text { Takt time }=\frac{\text { available work time per week }}{\text { customer demand per week }}
$$

Customer demand rate per week

$=(1800$ units $/$ month $) /(4$ weeks $/$ month $)=473$ unit $/$ weeks

Available time percentage obtained information that the production of fan type $1651 \mathrm{KP}$ reaches $45 \%$ compared with other types of products produced in the company. So that available time of 480 minutes working hours per day, for $1651 \mathrm{KP}$ fan is 216 minutes or 12,960 minutes. Takt time calculation is done starting at each work station, and 
starting from the last process is on the product gasket until the mixing of raw materials.

Customer demand rate per week on fan packing product will be the basis of customer demand rate calculation in previous process, that is assembling process in accordance with push system principle.

Comparison between takt time and cycle time of production obtained from observation can be seen in Table 1 .

Tabel 1. Comparison of cycle time and takt time

\begin{tabular}{|l|c|c|}
\hline \multicolumn{1}{|c|}{ Activity } & Cycle Time & Takt time \\
\hline Mixing raw materials & 21,36 & 28,51 \\
\hline Molding dop hinge & 46,62 & 27,36 \\
\hline Molding rotary switch & 35,11 & 27,36 \\
\hline Molding dynamo's dwell & 51,55 & 27,36 \\
\hline Molding dynamo's cap & 50,15 & 27,36 \\
\hline Molding plastic nuts & 38,42 & 27,36 \\
\hline Molding fan leaf & 49,80 & 27,36 \\
\hline Molding casing logo & 35,73 & 27,36 \\
\hline Molding hinge fan stand & 39,86 & 27,36 \\
\hline Molding front casing & 35,48 & 27,36 \\
\hline Molding back casing & 35,45 & 27,36 \\
\hline Molding casing button & 34,66 & 27,36 \\
\hline Molding fan tread stand & 47,87 & 27,36 \\
\hline $\begin{array}{l}\text { Installation of bottom tread } \\
\text { with spare parts }\end{array}$ & 9,20 & 28,80 \\
\hline Assembly & 18,32 & 28,80 \\
\hline Packing & 13,40 & 28,51 \\
\hline
\end{tabular}

From the table above the time process under takt time indicates the process run faster or can meet the demand. The production process in this state is not very good, but it needs to be analyzed whether there is a surplus of labor that can be reduced to balance the workload of other stations. Process time under takt time is the process of mixing raw materials, molding rotary rotary switch components, molding chasing component logo, front chasing component molding, rear chassis component molding, button chasing component molding, spare part assembly, assembly assembly, and Packing.

Stations with processing time above takt time indicate the process is running slower than it should be. The process is molding component dop hinge, house dynamo component molding, dynamo-housing component molding, molding plastic nuts components, molding fan leaf components, molding fan stand hinges, and molding stand fan footprint components. Improvements that can be made to adjust to takt time are by reducing batch size of production, improving working methods by reducing inefficient activity or increasing labour amount.

\subsection{Current state map analysis}

\subsubsection{Waste identification with PAM}

In identifying the existence of non-value added activities for the company, these observations are made directly to the company's production floor. With the observation supported by interviews with employees and supervisors, therefore can be seen whether or not there is waste in the company. In addition, a method that can be used to identify waste is Process Activity Mapping (PAM).

Recapitulation of Process Activity Mapping (PAM) results can be seen in Table 2 .

Table 2. Recapitulation of number and time of PAM result of fan production process type $1651 \mathrm{KP}$

\begin{tabular}{|l|c|c|}
\hline \multicolumn{1}{|c|}{ Activity } & Numbers & Time (Minutes) \\
\hline Operation (O) & 22 & 77,74 \\
\hline Transportation (T) & 19 & 72,58 \\
\hline Inspection (I) & 5 & 15,52 \\
\hline Delay (D) & 13 & 581,40 \\
\hline
\end{tabular}

Based on the identification of process activities contained in the production line

\subsubsection{VA dan NVA analysis}

In this stage will be grouped activities that include value added and non-value added. The value of value added time is obtained from the process time contained in the current state map. While non value added time is the lead time of each process which is also found in current state map. Grouping for value added activity can be seen in Table 3 .

Table 3. Value added activity

\begin{tabular}{|c|l|c|}
\hline No & \multicolumn{1}{|c|}{ Value Added Activity } & $\begin{array}{c}\text { Time } \\
\text { (Minutes) }\end{array}$ \\
\hline 1 & Raw materials are weighed & 1,95 \\
\hline 2 & $\begin{array}{l}\text { The calcium carbo extract is } \\
\text { weighed }\end{array}$ & 1,82 \\
\hline 3 & $\begin{array}{l}\text { The colour flour enhancement is } \\
\text { weighed }\end{array}$ & 1,19 \\
\hline 4 & Mixing Raw Materials & 12,18 \\
\hline 5 & Issued from mixing machine & 1,59 \\
\hline 6 & Molding dop hinge & 1,17 \\
\hline 7 & Molding rotary switch & 1,22 \\
\hline 8 & Molding dynamo's dwell & 1,23 \\
\hline 9 & Molding dynamo's cap & 1,3 \\
\hline 10 & Molding plastic nuts & 1,17 \\
\hline 11 & Molding fan leaf & 1,38 \\
\hline 12 & Molding casing logo & 1,19 \\
\hline 13 & Molding hinge fan stand & 1,4 \\
\hline 14 & Molding front casing & 1,2 \\
\hline 15 & Molding back casing & 1,17 \\
\hline 16 & Molding casing button & 1,17 \\
\hline 17 & Molding fan tread stand & 1,11 \\
\hline 18 & $\begin{array}{l}\text { Installation of bottom tread with } \\
\text { spare parts }\end{array}$ & 1,28 \\
\hline 19 & Assembly & 26,98 \\
\hline 20 & Packing & 16,04 \\
\hline & & 77,74 \\
\hline & & \\
\hline
\end{tabular}


Grouping for non value added activities can be seen in Table 4.

Table 4. Non value added activity

\begin{tabular}{|l|l|c|}
\hline $\begin{array}{l}\mathbf{N} \\
\mathbf{o}\end{array}$ & Non Value Added Activity & $\begin{array}{c}\text { Time } \\
\text { (Minutes) }\end{array}$ \\
\hline 1 & $\begin{array}{l}\text { The raw material is brought to } \\
\text { the mixing machine }\end{array}$ & 1,32 \\
\hline 2 & $\begin{array}{l}\text { Additional calcium carbo } \\
\text { ingredients are brought to the } \\
\text { mixing machine }\end{array}$ & 1,28 \\
\hline 3 & $\begin{array}{l}\text { The colour flour enhancer is } \\
\text { brought to the mixing machine }\end{array}$ & 1,19 \\
\hline 4 & Moved to a molding machine & 2,56 \\
\hline 5 & $\begin{array}{l}\text { Components stacked waiting in } \\
\text { transport }\end{array}$ & 572,58 \\
\hline 6 & Bring it to the assembly line & 61,92 \\
\hline 7 & Spare parts waiting for the raft & 8,82 \\
\hline 8 & $\begin{array}{l}\text { Spare parts are transported to } \\
\text { the assembly line }\end{array}$ & 1,21 \\
\hline 9 & Vane testing & 1,96 \\
\hline 10 & Check the assembly results & 7,54 \\
\hline 11 & $\begin{array}{l}\text { Transport to a temporary } \\
\text { buildup }\end{array}$ & 3,12 \\
\hline
\end{tabular}

Comparison between value added (VA) and non-value added (NVA) can be clearly seen in Figure 2.

\section{Comparison of Activity Percentage between Value Added and Non Value Added}

\section{- Value Added $\quad$ Non Value Added}

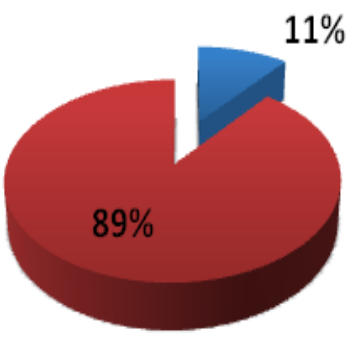

Figure 2. Comparison between value added and non value added.

\subsubsection{Cycle time analysis}

The cycle time of each process that is a value added time sometimes has non value added elements in it called non value creating time. Overly long cycle times in the processing of a process can also lead to non-value creating time. For example, in parts molding components, long cycle time causes workers on the molding component is often idle so that this activity is classified as waste. Analysis of improvements made to reduce cycle time that will be explained in the proposed further improvement given.

\subsubsection{PAM analysis by using $5 \mathrm{~W} 1 \mathrm{H}$ method}

Based on the results of the identification of process activities contained in the production line will be eliminated or reduce activities that are considered not have added value. In addition, it will also consider improvements in activities that can minimize production process time to be shorter. There are some non-value-added and evaluable activities totalling 17 , among others, 2, 4, 6, 11, 15, 18, 21, 24, 27, 30, 33, 36, 39, 42, 45, 47 and 59 This is based on direct observation and discussion result due to excessive activity and production process and not added value so it will affect to lead time.

\subsubsection{Waste analysis in process}

Waste in waiting time that often occurs in the production process at the factory, after that sought the cause by using tools 5 why that can be seen in Table 5 .

Table 5. Use of the 5 whys method in troubleshooting

\begin{tabular}{|l|l|l|}
\hline No & \multicolumn{2}{|l|}{$\begin{array}{l}\text { Problem: There is a long lead time production } \\
\text { in the form of waiting time }\end{array}$} \\
\hline 1. & $W h y$ & $\begin{array}{l}\text { The flow of the production process is } \\
\text { gradual or not flowing }\end{array}$ \\
\hline 2. & $W h y$ & $\begin{array}{l}\text { The product components accumulate a } \\
\text { long time to perform the next stage of the } \\
\text { production process. }\end{array}$ \\
\hline 3. & $W h y$ & $\begin{array}{l}\text { The old product component is transported } \\
\text { to the assembly line }\end{array}$ \\
\hline 4. & $W h y$ & $\begin{array}{l}\text { Material transportation is repeated using } \\
\text { manual method }\end{array}$ \\
\hline 5. & $W h y$ & $\begin{array}{l}\text { Limited number of material handling } \\
\text { available and irregular workplace }\end{array}$ \\
\hline
\end{tabular}

From the table above can be concluded that the root of the problem of the occurrence of waste of waiting time due to the limited number of material handling and the number of workers for some long production process that takes a long time to workmanship requires more time. In addition to analyse the waste that occurred, also conducted an analysis of the results of calculation take time lower than cycle time that occurs in some processes.

\subsection{Formation of future state map}

\subsubsection{Preparation of improvement efforts}

After it is known that the cause of the waste occurring that causes the high value of non-value added time, then further effort will be made to reduce the non-value added time based on the root cause analysis of the waste that has been explained previously. Based on the root of the problem described above, it can be made a corrective action plan to minimize waste in the form of waiting time. The root of the problem shows the limited number of material handling and the number of workers and the irregularity of the work area on the production floor so that it needs to be repaired. Alternative possible improvements are made to each production activity to reduce waste in the form of waiting 
time, irregularity of the workplace, and the number of operators waiting. The alternatives can be seen in Table 6 .

Table 6. Alternative improvements for each production activity

\begin{tabular}{|c|c|c|}
\hline No & Roots of Problems & $\begin{array}{c}\text { Alternatives } \\
\text { Improvement }\end{array}$ \\
\hline 1. & $\begin{array}{l}\text { Raw materials and } \\
\text { auxiliary materials } \\
\text { in the raw material } \\
\text { warehouses await } \\
\text { the stages of the } \\
\text { process before } \\
\text { mixing the raw } \\
\text { materials. }\end{array}$ & $\begin{array}{l}\text { Adds the number of } \\
\text { workers and job } \\
\text { arrangements to the mixing } \\
\text { of raw materials }\end{array}$ \\
\hline 2. & $\begin{array}{l}\text { Manual removal } \\
\text { resulting in } \\
\text { repetitive transfers }\end{array}$ & $\begin{array}{l}\text { Adding semi-automatic } \\
\text { material handling to make } \\
\text { it easier for employees to } \\
\text { do material handling. }\end{array}$ \\
\hline 3. & $\begin{array}{l}\text { The length of } \\
\text { waiting time for the } \\
\text { product } \\
\text { components from } \\
\text { the result of } \\
\text { molding machine }\end{array}$ & $\begin{array}{l}\text { Improved working } \\
\text { procedures in work } \\
\text { procedures and operator } \\
\text { expertise in using molding } \\
\text { machines }\end{array}$ \\
\hline 4. & $\begin{array}{l}\text { The existence of } \\
\text { waiting products } \\
\text { assembled on } \\
\text { assembly lines } \\
\text { between } \\
\text { assemblers one } \\
\text { with other } \\
\text { assemblers }\end{array}$ & $\begin{array}{l}\text { Improve working } \\
\text { procedures and also train } \\
\text { operators to balance during } \\
\text { assembly process. }\end{array}$ \\
\hline 5 & $\begin{array}{l}\text { Irregularity of the } \\
\text { breaking of the } \\
\text { components } \\
\text { coming from the } \\
\text { molding machine } \\
\text { to assembly section }\end{array}$ & $\begin{array}{l}\text { Adding the container as a } \\
\text { place to lay WIP } \\
\text { components so as not to } \\
\text { scatter. }\end{array}$ \\
\hline
\end{tabular}

\subsubsection{Depiction of future state map}

Improvements made are drawn in the future state map and calculated lead time result proposed improvement. The time change included is a time change that can be observed or estimated from the current state. The picture of the proposed future state map can be seen in Figure 3. The implementation of the 5 whys strategy and the analysis using PAM (process activity mapping) on the fan production process will be able to reduce the product components that accumulate and reduce the waiting time that occurs. So it can reduce waste (waste) in the process of fan production.

\section{Conclusion}

Based on the theoretical basis, the results of research and analysis have been done then it can be concluded that there is several non-value added activities which in a very significant amount at present state map with total time of 647.94 minutes of total lead time of 725.68 minutes. Through estimation of improvement result obtained Total lead time in future state map is 250,80 minutes. Value stream mapping showed a decrease in total lead time of 340.9 minutes. The saving of working hours will directly increase the fan production capacity without having to increase the input used in the production process resulting in increased productivity.

\section{References}

1. Wilson, Lonnie. How To Implement Lean Manufacturing. New York: McGraw-Hill, (2010).

2. Nash, Mark and Polling, Sheila. 2008. Mapping The Total Value Stream. Taylor and Francis Group.

3. Salunke, Shweta S dan Hebbar, Sunith. Value Stream Mapping: A Continuous Improvement Tool for Reduction in Total Lead Time. International Journal of Current Engineering and Technology. India: Engineering Management, Manipal Institute of Technology, (2015).

4. Batra, Kritika. Dkk. Study on Application of Lean Manufacturing Tools for Performance Improvement. India: Department of Mechanical Engineering, Delhi Technological University, (2015) 